\title{
DIE ONGETROUDE VOLWASSE TSWANA-VROU SE PERSEPSIES VAN DIE HUWELIK
}

\author{
A Erasmus \\ Potchefstroom \\ EH Ryke \\ Potchefstroom Kampus van die Noordwes-Universiteit
}

\begin{abstract}
The objective of this article is to explore and describe the adult unmarried Tswana woman's perceptions of marriage in order to contribute to the development of indigenous knowledge as a basis for culture congruent marriage preparation services. For these purposes a qualitative, exploratory research study has been undertaken. Thirty-two Tswana women, who met all the set criteria, were included in the study by means of purposive sampling. An in-depth exploration of the perceptions of unmarried mature Tswana women was undertaken by utilising the semi-structured method of interviewing. Relevant data were analysed by means of descriptive analysis as described by Tesch. A variety of factors that influence the adult unmarried Tswana woman's perceptions of marriage, such as the traditional and changing role and status of the married woman, the high divorce rate, the bogadi-and stay at in-lawscustom, and the Tswana woman's expectation of a spouse, have been identified. In this article the findings of this study is presented and discussed, and recommendation regarding culture congruent marriage preparation services made.
\end{abstract}

\section{INLEIDING}

Die vraag na huweliksberading onder jong swart vroue het skerp toegeneem (FAMSA-Noordwes, Jaarverslag, 2001). Die groot gebrek aan inheemse kennis ten opsigte van maatskaplikewerkhulpverlening aan swart kulture in Suid-Afrika bemoeilik dit vir die Westerse maatskaplike werker om kultuurkongruente dienste te lewer. Du Preez en Van Niekerk (1988:154-155) kom tot die gevolgtrekking dat die eiesoortige problematiek van swart mense wat 'n hoë graad van verwestering bereik het, nie aandag in die teoretiese inhoud van huweliksvoorbereiding en berading geniet nie. Maatskaplike werkers se kennis van die gesinslewe en huwelik is grootliks gebaseer op Westerse bronne wat nie volkome van toepassing op swartgroepe is nie (Kimathi, 1994:7). Sikhitha (1996:61) stel dit dan ook tereg dat die literatuur in Suid-Afrika rakende transkulturele werk steeds onvoldoende ontwikkel is.

Die doel van hierdie artikel is om verslag te doen oor " $\mathrm{n}$ studie wat onderneem is rakende die ongetroude volwasse Tswana-vrou se persepsies van die huwelik en daardeur ' $n$ bydrae te lewer tot die ontwikkeling van inheemse kennis as grondslag vir kultuurkongruente dienste in maatskaplike werk. In die artikel word die navorsingsmetode wat gevolg is en agtergrond oor die Tswana-huwelik beskryf. Daarna word die bevindinge van die studie bespreek en aanbevelings vir kultuurkongruente huweliksvoorbereiding gemaak.

\section{NAVORSINGSMETODE}

'n Kwalitatiewe, verkennende ondersoek (Strydom, 2000:74) is onderneem. Twee en dertig Tswana-vroue, wat aan al die gestelde kriteria vir hierdie ondersoek voldoen het, is by die ondersoek ingesluit. Dié Tswana-vroue het bestaan uit 10 graad 12-dogters, 12 vroulike 
universiteitstudente en 10 vrywilligers van `n plaaslike welsynsorganisasie. Semi-gestruktureerde onderhoudvoering (Strydom, 2000:121) is as data-insamelingsinstrument gebruik terwyl data met behulp van Tesch se benadering ontleed is (Poggenpoel, 1998:343). `n Medekodeerder is gebruik om die betroubaarheid van resultate te verhoog. Na die voltooiing van die data-analise is die bevindings aan die hand van relevante vakliteratuur gekontroleer (Woods \& Catanzaro, 1988:135).

\section{AGTERGROND}

Volgens Schapera (1994:4) kom agt hoof Tswana-stamme in Suid-Afrika voor waarvan elk histories onderverdeel is. Met die bespreking van gebruike binne die Tswana-kultuur, byvoorbeeld wat die huweliksprosedure betref, bestaan kleinere verskille van stam tot stam, maar die algemene prosedure is fundamenteel dieselfde (Schapera, 1994:130-131).

Die Tswana-huwelik is tradisioneel deur die betrokke jongmense se ouers gereël, sonder dat die jongmense enige sê daarin gehad het. Die tradisionele Tswana-huwelik is voorts slegs as geldig beskou indien die kontrakterende partye aan onder andere die volgende vereistes vir die Tswanahuwelikskontrak voldoen het:

- Die wedersydse ooreenkoms tussen die twee betrokke families, soos weerspieël in die formaliteite van die verlowing.

- Die oordrag van vee, gewoonlik beeste (bogadi), van die bruidegom se familie aan dié van die bruid (Schapera, 1994:125). In Tswana word die term bogadi gebruik om die oordrag van huweliksgoedere aan te dui (Schapera, 1994:125).

Die onderdanige rol en status wat die Tswana-vrou in die huwelik beklee het, is nog 'n onmiskenbare kenmerk van die tradisionele Tswana-huwelik. Tot onlangs was die swart vrou nog beskou as die "besitting" van haar vader, en na die huwelik, die "objek" van haar man (Mashishi, 2000:82). Die tradisionele swart huwelik was dus in die verlede primêr 'n ekonomiese en voortplantingseenheid en die vrou was derhalwe as ekonomies voordelig beskou (Steyn, 1999:58).

Daar het egter aansienlike veranderinge in die Tswana-huwelik, sowel as die Tswana-vrou se rol en status binne die huwelik plaasgevind. Twee faktore het hoofsaaklik hierin ' $n$ rol gespeel: die bewuswording van Westerse huweliksgebruike en die veranderde gebruike ten opsigte van bogadioordrag (Schapera, 1971; Schapera, 1994:125). Die hedendaagse Tswana-vrou is nie meer bereid dat haar waarde bepaal word deur haar voortplantingsvermoë nie (Steyn, 1999:59). Haar persepsies van die huwelik is dikwels Westersgeoriënteerd en haar emosionele en persoonlike behoeftes is ook in pas met dié van 'n hedendaagse Westerse vrou.

\section{BEVINDINGE}

Die bevindinge word bespreek aan die hand van die vier kategorieë wat die resultaat van die inhoudsanalise van die semi-gestruktureerde onderhoude was, naamlik die rol en status van die Tswana-vrou: tradisioneel en hedendaags, haar huwelikstatusvoorkeur, huweliksgebruike - toe en nou - en haar verwagtinge van 'n huweliksmaat. Elke kategorie word in sub-kategorieë verdeel. Sub-kategorieë verskyn in vetletterdruk. Grepe uit die antwoorde van deelnemers wat tydens die onderhoudvoering bekom is, word ter stawing van sommige stellings bygevoeg. Hierdie antwoorde word in kursiewe druk weergegee.

\section{Die Tswana-vrou se rol en status in die huwelik: tradisioneel en hedendaags}

Die deelnemers aan die ondersoek het baie klem gelê op die onderdanige rol en status wat die vrou in die verlede in die tradisionele Tswana-huwelik beklee het: "Back then your women use to like 
get forced to stay at home ... their role was to cook, clean, make babies, look after the babies ...". Verskeie navorsers bevestig hierdie posisie wat die Tswana-vrou in die tradisionele huwelik beklee het (Laville, 1999:151; Mashishi, 2000:82; Steyn, 1999:58).

Deelnemers was dit eens dat die rol van die Tswana-vrou binne die huwelik hedendaags drasties verander het. Klem is op drie veranderde terreine gelê:

- Die hedendaagse Tswana-vrou het die geleentheid om ook 'n beroep te beoefen: “... now women can work ... In the old days, the woman's place was in the kitchen staying home ...".

- Die Tswana-vrou kan ook haar stem laat hoor en aandag aan die vervulling van haar eie behoeftes gee: “... because at first women were oppressed ... nowadays women speak loud and they have to do what's right for them and ... what's best for them. At the past women ... she didn't have to talk anything, even if she was hurt or what".

- Sy beklee ook binne die huwelik 'n meer gelyke rol: “... before women would be ... the servants ... Now it's like a 50/50 situation ... they help each other".

Veral twee betekenisvolle gebeurtenisse in die geskiedenis van Suid-Afrika het dié rol van die vrou aansienlik verander, naamlik verstedeliking (Steyn, 1999:58) en die instel van gelyke regte tussen mans en vroue (Levitz, 1995:25). Van Zyl (1994:4) stel dit dat hoewel vroue tans oor gelyke regte beskik, die omstandighede egter steeds dieselfde bly. Baie swart vroue beklee steeds ' $\mathrm{n}$ ondergeskikte rol in die huwelik.

'n Balans tussen die vrou se nuutgevonde onafhanklikheid en haar tradisionele verpligtinge is deur deelnemers beklemtoon. Hierdie navorsingsresultaat was egter tiperend van die graad 12 dogters se respons. Volgens hulle kan die misbruik of wangebruik van haar nuutgevonde regte en alles wat daarmee gepaard gaan, op hul beurt weer nadelig vir die vrou, haar huwelik en haar hele gesin wees. Hulle het van die standpunt uitgegaan dat die hedendaagse Tswana-vrou soms só vasgevang raak in haar beroep dat sy haar huishoudelike take en gesin verwaarloos. “... they are a wife, a mother, a business woman, all these things in one, or they're neglecting one of the roles that they have to play in their home. So I think that you find these kind of women that ... the two different types where one is able to be all these things in one and still be a good homemaker and the one who's neglecting all these things that she has to ...".

Deelnemers het ook Tswana-vroue wat die beroepswêreld betree, se gebruik van steunstelsels aangeraak. Steunstelsels gee ook die Tswana-vrou meer tyd om aan haar beroep of met haar gesin te bestee, sonder dat sekere verantwoordelikhede verwaarloos word. Verskeie skrywers (Naude, 1998:14-15; Van Zyl, 1994:4-5; Van Zyl, 1996:21-23) bevestig ook die belangrikheid van die benutting van steunstelsels deur werkende vroue.

\section{Voorkeur ten opsigte van huwelikstatus}

By die toetsgroep was ' $n$ duidelik teenstrydige uitgangspunt oor hulle voorkeur ten opsigte van huwelikstatus. Daar was diegene wat trou as 'n lae prioriteit beskou, diegene wat graag wil trou en dié wat nie wil trou nie. Beide groepe wat wil trou en nie wil trou nie, word deur 'n negatiewe persepsie van die huwelik beïnvloed. Dié negatiewe persepsie is gebaseer op hul siening dat die egskeidingsyfer hoog is en baie getroude mans ontrou aan hul huweliksmaats is.

Dié deelnemers wat laat blyk het dat die huwelik glad nie `n prioriteit is nie, meld dat dit nie ' $\mathrm{n}$ saak is waaroor hulle hulle bekommer nie: "I won't say I want to get married. If I'm married, I'm married ... If I'm not married, I'm not. It's not something that cross my mind; I don't think of it." 
Daar was ook opmerklike resultaatverskille binne die drie toetsgroepe. Dit is veral die graad 12dogters wat graag sal wil trou en die vrywilligergroep wat teen ' $n$ huwelik gekant is. Die deelnemers se lewensfase het moontlik die primêre invloed op hierdie verskille in resultate gehad. So beweeg die graad 12-dogters en universiteitsmeisies in kringe waar hubare mans redelik algemeen voorkom. Die vrywilligers van " $n$ welsynsorganisasie beweeg egter reeds in die "wêreld daar buite" en het nie die hulp van 'n instansie wat vir die ongetroude vrou meer moontlikhede skep om 'n lewensmaat te ontmoet nie. South (1993:357-358) bevestig hierdie verskynsel. Norment (1998:2) en Van der Vliet (1991:236) bevestig dat sommige swart vroue vandag verkies om nie in die huwelik te tree nie.

Verder het die meeste deelnemers, maar veral die graad 12-dogters en universiteitsmeisies, steeds 'n baie idealistiese persepsie ten opsigte van die huwelik. Woorde soos "love", "sharing", "commitment", "caring", ensovoorts, is algemeen in hul beskrywing gebruik. Die vrywilligers van die welsynsorganisasie, daarenteen, het dikwels reeds die werklikheid van die huwelik in hul daaglikse bestaan waargeneem en is om dié rede moontlik in 'n groter mate teen die huwelik gekant. Tiperend van die vrywilligers van die welsynsorganisasie se antwoorde was dat hulle Tswana-mans as "abusive", "not trustworthy" en "cheating on their wives" beskou en dat dit moeilik is om `n man met goeie eienskappe te vind.

Die sistematisering van die ongetroude volwasse Tswana-vrou se persepsies van die huwelik kan as uniek vir hierdie ondersoek beskou word, aangesien geen relevante vakliteratuur wat hierdie ondersoekveld dek, gevind kon word nie. Die deelnemers se beskrywing van die huwelik stem egter in 'n groot mate ooreen met die Westerse beskouing van die huwelik. Lasswell en Lasswell (1991:217) gebruik byvoorbeeld baie begrippe wat ook in die beskrywing van deelnemers wat ten gunste van die huwelik was, na vore gekom het: “... Sharing love, companionship, decisions, goals and time together ... adopting to the inevitable changes while maintaining the stability necessary for commitment ... meeting individual needs as well as working toward mutual goals ..."

Uit die navorsingsresultate blyk dat `n aantal veranderlikes tans binne die huwelik voorkom wat `n negatiewe persepsie van die huwelik tot gevolg het. Dit skyn of die ongetroude volwasse Tswana-vrou graag in die huwelik wil tree, maar dat sy terselfdertyd besef waaraan sy haar dan moontlik sal blootstel. Selfs deelnemers wat aan die begin van die onderhoud ten gunste van die huwelik was, het met verloop van die onderhoud al meer negatief oor die huwelik begin praat. Dit is dus duidelik dat die gedagte aan `n huwelik interne konflik by hierdie vroue veroorsaak: “... I'm not really for marriages really ... I want to get married, but in these days I'm not really sure 'cause... I don't think that people take marriages serious these days". Volgens South (1993:357) verwag nie almal wat graag wil trou, om te trou nie, en dié wat verwag om te trou, kan steeds ernstige bedenkinge hê oor die wenslikheid van trou. Hierdie persepsie blyk ook aanwesig te wees by die ongetroude volwasse Tswana-vrou.

Dit het herhaaldelik in antwoorde na vore gekom dat die hoë egskeidingsyfer van vandag moontlik die primêre rede is waarom die ongetroude volwasse Tswana-vrou verwarring en selfs vrees ten opsigte van die huwelik beleef: "There's no marriage nowadays, so I don't want to hurt myself for a time to get married if ... for a time then get divorced, I don't want to do that. Marriage just ends up in divorce ...". Hendrick en Hendrick (1992:200) bevestig dat "egskeiding" juis as rede voorgehou word om nie in die huwelik te tree nie: "Because of the frequency of divorce in society, you are very likely to have personal knowledge of divorce, either as children in a family in which the parents have been divorced or as relatives or friends of a divorcing couple ... you probably know firsthand the mixed feelings, the pain and loss, and the revitalization that may accompany divorce." 
Tog word egskeiding deur deelnemers as `n redelik onbekende verskynsel binne die Tswanatradisie beskou: "... because long ago there was no divorce, and for now divorce is like too many times ... before there were no... their parents will come and talk and talk and help for a marriage to stay long ... to protect the marriage...". Schapera (1994:159) bevestig hierdie siening en noem dat, indien daar wel probleme in die huwelik voorgekom het, die ouers van albei kante by die vrou se familie bymekaargekom en gepoog het om vrede tussen die man en vrou te bewerkstellig.

Deelnemers uit al drie groepe, maar veral die vrywilligers van die welsynsorganisasie, het klem gelê op ontrouheid binne die huwelik: "It (adultery) is one of the things that makes ... all the divorces." Schapera (1994:156) verduidelik dat die Tswana-man en -vrou ná die huwelik teoreties aan mekaar getrou moet bly, maar volgens Steyn (1999:58) gaan die swart man egter steeds voort met die "tradisionele" sanksionering van meervoudige seksuele verhoudings en beskou hy dit as sy reg om fisiese verbintenisse buite die huwelik te hê.

Deelnemers wat die onderwerp van "ontrouheid" aangeraak het, was dit eens dat die feit dat mans ontrou is, hulle ontstel. Gevoelens soos "angry", "confused", "hurt", "disgusted" en "discouraged" het herhaaldelik na vore gekom: "It makes you feel small, confused and angry ... towards this lady and this man ...". In die tradisionele Tswana-huwelik het die vrou nie die reg gehad het om haar man bloot weens sy ontrouheid te verlaat nie. Volgens die Tswana-kultuur was sy slegs toegelaat om haar man te verlaat indien ontrouheid met ander vorme van verwaarlosing en mishandeling gepaard gegaan het (Schapera, 1994:157).

Dit was ook duidelik dat die ontrouheidsdaad as sodanig die ongetroude volwasse Tswana-vrou dikwels minder ontstel as die feit dat die hedendaagse man gewoonlik sy eie vrou en kinders "afskeep" as hy 'n buite-egtelike verhouding het. "In the past, even if the husband was cheating, he will not show his wife that he's cheating, he'll always be there for her ... there for her and the children ...". Schapera (1994:156-157) ondersteun hierdie waarneming: "If the husband is unfaithful to his wife, she appears in general to be fairly complacent about it, as long as he continues to look after her decently, sleeps with her regularly, and does not obviously favour his concubine ... But sometimes the wife is less accommodating, especially if her husband neglects her altogether, as so often tends to be the case."

Deelnemers het veral klem gelê op vyf oorsake van ontrouheid: die man is tuis seksueel onbevredig; 'n gebrek aan kommunikasie wat tot die misverstand en onkunde oor mekaar se behoeftes lei; die man wat in die huwelik tree sonder dat hy sy eggenote werklik ken; die man wat besef dat sy vrou niks aan sy ontrouheid kan doen nie; en die vrou wat nie finansieel tot die huishouding bydra nie. Dié beklemtoning illustreer die heersende teenstrydigheid in denke by Tswana-vroue in hul strewe enersyds na eiewaarde en outonomie en dié minderwaardige uitgangspunt: As my man ontevrede met my of ons huwelik is, het hy regverdiging om ontrou te wees.

$\mathrm{Al}$ die deelnemers wat ten gunste van die huwelik is, het verklaar dat hulle eers op `n later stadium in hul lewe in die huwelik wil tree - in hul laat twintigerjare of selfs vroeë dertigerjare - aangesien hul onafhanklikheid vir die deelnemers die hoogste prioriteit geniet. Onafhanklikheid is byna deurlopend in verband gebring met opleiding en ' $n$ beroep. Weens hul onafhanklikheidstrewe word 'n hoër ouderdom vir huweliksluiting geantisipeer: "About 28 ... because I want to be stable at my career, I want to study ...I want to be independent". South (1993:357-358) bevestig hierdie verskynsel. "Growing financial independence and increased educational opportunities, in conjunction with reduced childbearing responsibilities, have allowed women to delay, and sometimes eschew, the adoption of marital and familial roles." Dobson en Houseknecht (1998:1) 
dui ook aan dat tersiêre opleiding die ouderdom by `n eerste huweliksluiting vir swart sowel as wit vroue verhoog.

Die uitstel van huweliksluiting is egter in direkte teenstelling met die tradisionele Tswana-gebruik. Schapera (1994:130) noem dat meisies tradisioneel dikwels baie jonk in die huwelik moes tree, omdat `n pa soms `n meisie, wat baie jonk was of selfs nog nie eers gebore was nie, as sy seun se vrou "bespreek" het. Dit was duidelik dat die vroue sterk voel oor opleiding en onafhanklikheid, juis omdat hulle besef wat hul voorgangers se posisie daarsonder was: “... Independent because they've seen what happened back in the day that your husband was cheating on you, it was just fine, you sit down and take it, because you got no education, no nothing. You just depend on him, you got married at the age of 17, you've got no education to work with, no one is going to hire you ...".

In reaksie op die vraag: "What is the most important thing for you personally: 1) a successful career, or 2) a happy marriage?" was die antwoord oorwegend ten gunste van "n suksesvolle loopbaan omdat die persepsie bestaan dat die huwelik van vandag dikwels in 'n egskeiding eindig en dat die vroue "iets wil hê om op terug te val": "I want to be independent. Ja, and then if I have to get married then, not being successful career wise, what if that husband divorces me for another ... and then it's going to be a problem for me. That is why I say I care to be successful in my career". Selfs die groep wat 'n huwelik verkies het, het steeds 'n suksesvolle beroep eerste gestel: "... first and far most my success as a business woman would come first ... and on the other hand, I want to be a good wife and have a beautiful marriage ...".

Sulke antwoorde beklemtoon weer eens die interne konflik by Tswana-vroue. Gevolglik dus hul voorkeur om "n "agterdeur" oop te hou om self hul eiewaarde en outonomie te verseker. Die Tswana-vrou wil dus nie toelaat dat haar man haar lot beskik nie. Ook aanvaar sy nie noodwendig dat sy vir lank geborge by hom sal voel nie.

\section{Huweliksgebruike: tradisioneel en hedendaags}

Rakende huweliksgebruike het die deelnemers klem laat val op die Tswana-huweliksprosedure, die bogadi-gebruik, die gebruik om na huweliksluiting by die skoonouers in te woon, asook die hedendaagse neiging om eerder saam te woon as om te trou.

Die Tswana-huweliksprosedure kan van stam tot stam verskil, maar die algemene prosedure is fundamenteel dieselfde (Schapera, 1994:130-131). Die keuse van 'n huweliksmaat is die eerste stap tot die huwelik. Die jong ongetroude Tswana-meisie kan vandag haar eie huweliksmaat kies, maar dit is `n voorreg wat sy nie altyd gehad het nie: “... Long ago it was planned and it was like you were forced and you were told ...". Schapera (1994:128) bevestig dat as gevolg van die toenemende onafhanklikheid van die jonger geslag dié gebruik ál minder voorkom.

Bogenoemde stap word opgevolg deur die seremoniële betaal van bogadi. Die jong man se ouers gaan na die meisie se ouers om oor die bedrag van bogadi te onderhandel: "... lobola is a small ceremony where the girl's uncle and parents and the guy's parents and uncle come together and negotiate on an amount. The girl's side has to decide on an amount that the guy will pay and ... people would gather around ... and drink beer and stuff".

Hierdie "onderhandeling" is lynreg teen Schapera (1994:140) se beskrywing van die bogadiprosedure: "Every family gives as much as it can afford or wishes. Nor is there any discussion beforehand between the two families as to the number to be given. There is none of that preliminary bargaining found ...”. Schapera se beskrywing van hierdie gebruik is waarskynlik 'n voorbeeld van die verskil in gebruike tussen die verskillende Tswana-stamme. Op grond van die 
antwoorde van sommige Tswana-vroue kon afgelei word dat die "uncle" of "Malumni" aan die man, maar veral aan die meisie se kant, 'n baie belangrike rol tydens die bogadi-prosedure speel.

Die verlowing vind plaas na die onderhandeling en die betaal van bogadi. Geen vasgestelde tydperk vir verlowing word neergelê nie en dit hang vandag grootliks van die paartjie se eie beplanning af: "... Some people pay lobola lets say maybe this weekend and then the next weekend they get married. Some people maybe after a year or after two years; it depends on how you plan ...”. Schapera (1994:132) noem egter dat min verlowings korter as 'n jaar duur en dat die meerderheid ten minste twee jaar duur. Dit wil egter voorkom of hy nie die faktor van "eie beplanning" in berekening bring nie. Sommige Tswana-paartjies raak glad nie voor huweliksluiting verloof nie: “...they just pay lobola and then get married after that".

Dit was duidelik dat die huwelikseremonie self steeds `n baie groot gebeurtenis in die Tswanakultuur is. Dit skyn of dié seremonie oor die algemeen oor twee dae strek, waarna die jong bruid dan volgens die Tswana-gebruik by haar skoonouers aan huis gaan bly (in gevalle waar hierdie tradisie steeds beoefen word): "Then you have two weddings; one day at the girl's house, the next wedding at the guy's and then it's like, that time you say that you welcome the bride. So the bride goes to the guy's family and then sometimes stay there for a while with the family". Schapera (1994:137) beskryf hierdie groot gebeurtenis só: "The wedding feast is an elaborate affair ... during which meat, beer, porridge, tea, and other foods are provided in abundance, specially rehearsed choirs of girls sing at both homes, and there is much general rejoicing ... On the first day the boy's people are entertained at the girl's home; on the second a feast is held at the boy's home ..."

Vandag kom hierdie gebruik, naamlik om ná die huwelikseremonie vir `n tydperk by die man se ouers tuis te gaan, al hoe minder voor. Dit blyk asof die pasgetroude Tswana-paartjie, soos die Westerse gebruik, nou verkies om direk na huweliksluiting met wittebrood te gaan - `n verskynsel wat onbekend in die tradisionele Tswana-huwelik was: “... nowadays they don't even think about going to the in-laws and they even go to the honeymoons ... before they didn't even know anything about that thing."

Die vroue het veral drie verskille tussen die Tswana- en blanke huwelikseremonies aangetoon. Eerstens het die Tswana-huwelikseremonie nie formele aspekte, byvoorbeeld die teken van 'n huweliksregister, soos by die blanke huwelikseremonie nie. Die Tswana-huwelikseremonie is voorts ' $\mathrm{n}$ langer prosedure met meer rituele as wat die geval by blanke huwelikseremonies is, en baie meer (selfs vreemde) gaste woon die Tswana-huwelikseremonie by - nie slegs familie en vriende soos by blanke huwelikseremonies nie. Derdens is die man en vrou se ouers nie so betrokke by die huwelikseremonie en die reël daarvan, soos by die blanke huwelikseremonie die geval is nie. Dit was opmerklik dat gemeen is dat die Tswana-huwelikseremonie vandag meer Westersgeoriënteerd moet wees: “... we no longer want to practise our culture and then we'll turn to ... do like Westerns ... we want our weddings to be more modernized". Schapera (1994:139) bevestig ook hierdie tendens.

Die hedendaagse bogadi-gebruik het aansienlike veranderinge ondergaan. Tradisioneel was bogadi met ' $\mathrm{n}$ geskenk van vee verbind. Vandag word bogadi feitlik sonder uitsondering in die vorm van geld betaal. ' $n$ Primêre rede vir bogenoemde skyn die veranderde status en hoër opleiding van die hedendaagse Tswana-vrou te wees: “... let's say you're intelligent and you've got degrees ... then obviously you're gonna go on a higher price kind of thing." Mvimbi (2000:120) bevestig dat opvoedkundige kwalifikasies 'n belangrike rol by die bogadionderhandelinge speel. Mvimbi (2000:120) bevestig ook dat groot bedrae geld tans vir bogadi 
betaal word: "But these days lobola has become nothing more than a shocking display of greed and money-grabbing. Huge amounts of money change hands ...".

Die dominante standpunt van vroue was dat mans wel bogadi moet betaal. Die redes wat aangevoer is, was egter grotendeels op die tradisionele doel van bogadi gebaseer. "... If there is a man that wants to marry you, your parents should see that that man is capable or is financially able ... to take care of their daughter, and it's a sign again for making friendship between the two families ...”. Kinders wat uit `n huwelik waar bogadi betaal is, gebore word, het sekere voorregte by die huis van hul moeder se familie, waarop hulle andersins nie geregtig sou wees nie. Volgens Schapera (1994:138) het `n vrou wat met bogadi getroud is, ook `n meer geëerde posisie in haar stam (Schapera, 1994:138, 139).

Sommige vroue is baie sterk teen die betaal van bogadi gekant, omdat hulle voel dat die betaal van bogadi hulle laat voel asof hulle verkoop word en dat die gebruik ook onregverdig is: “... the lobola is not even a quarter of the money that my parents spent to grew me up. And another thing is, that boy, also his parents grew him up and they use a certain money, so there's no need for him to pay so that he can get me. He can just get me if we love each other."

Die klem wat op die finansiële aspek van bogadi geplaas is, beklemtoon weer eens die interne konflik wat by Tswana-vroue bestaan: die besef van eiewaarde en outonomie naas die feit dat die bogadi-gebruik van hulle "objekte" maak met 'n "waarde" wat op akademiese kwalifikasies en status berus. Schapera (1994:138) bevestig dat die bogadi-gebruik van vandag sekere nadele inhou: `n vrou wat met bogadi getroud is, staan in 'n baie groter mate onder haar man se beheer iets wat by die vrou tot misbruik en die ondermyning van eiewaarde kan lei. Sommige vroue staan egter totaal apaties en onverskillig teenoor die bogadi-gebruik. "Lobola to me, it's no big deal. If they pay lobola for me ... if they don 't, it's fine ...".

Dit skyn of tradisie in die Tswana-kultuur baie belangrik is en dat sommige Tswana-mense alles in hulle vermoë sal doen om tradisie in stand te hou. "It is important that we do things in the traditional way because our culture is an important part of ourselves" (Makholwa, 1997:111). Sommige swart mense sien die bogadi-gebruik as `n Afrika-gewoonte wat hulle van die blankes onderskei en daarom behoue moet bly (Labuschagne, 1991:552). Makholwa (1997:111) benadruk dat die jonger generasie die kernbetekenis van tradisies soms uit die oog verloor.

Die tradisionele Tswana-gebruik dat die jong bruid direk na huweliksluiting 'n sekere tydperk lank saam met haar nuwe man by die skoonouers moet in woon (Schapera, 1994:148), word deur die deelnemers aan hierdie studie uitgelig as ' $n$ tradisie wat hulle nie meer wil onderhou nie. Die aanvanklike doel van hierdie tradisie was om op die huweliksaand vas te stel of die jong Tswanavrou steeds 'n maagd was: "There are things that have to be proven ... see that wife must be... have to be a virgin, so you stay in your in-laws to check if you are really still a virgin". Ook wou die jong Tswana-vrou se skoonmoeder sien of sy 'n goeie vrou vir haar seun sou wees en om dit aan haar te bewys, is verskeie take aan die nuwe skoondogter opgedra. Volgens Schapera (1994:149) word van die jong vrou verwag om nederig, eerbiedig en hardwerkend te wees en gevolglik die algemene "bediende" van die huishouding te wees.

Een van die deelnemers het die situasie van vandag soos volg beskryf: "Well, now they do it like white people and they just stay in their own house ...." Die oorwegende standpunt van die deelnemers was dat hulle beslis nie by hul toekomstige skoonouers wil inbly nie. Die vroue se afkeur van dié gebruik is primêr op hul intense behoefte aan waarde en outonomie gebaseer. Die vroue het die persepsie dat " $n$ bruid wat by haar skoonouers bly, dikwels soos 'n slaaf behandel word. Ook meen hulle dat een huishouding nie deur twee vroue bestuur kan word nie en dat konflik onvermydelik is: “... honestly, I'm gonna get married at a old age, so obviously I have my 
own money and ... I don't wanna be bossed around by some woman telling me what to do ... but I would like to move into my own house directly after we get married."

Ook lyk dit of die hedendaagse pasgetroude egpaar na die huwelik slegs by die man se ouers bly indien hulle nog nie reeds `n eie woning het nie. Schapera (1994:149) noem egter dat die Tswanavrou se lot baie makliker is wanneer haar man sy eie huis oprig en sy die meesteres daarvan word. Die vroue het egter indirek drie voordele genoem wat hierdie gebruik wel kan inhou:

| $\because$ Paartjies wat nog nie `n eie huis het nie, kan tydelik by die man se ouers aan huis bly, totdat hulle hul voete gevind het.

$\succeq$ Die bruid kan in hierdie tydperk 'n goeie verhouding met haar skoonouers opbou.

$\square$ Hierdie gebruik bied ook vir die bruid `n goeie leergeleentheid ten opsigte van haar man en skoonfamilie se gebruike.

Tydens die onderhoudvoering was die vroue oorwegend ten gunste van die bogadi-gebruik, maar baie definitief téén die gebruik om by die skoonouers te woon - gebruike wat albei deel van die Tswana-kultuur vorm. By die bespreking van bogadi is die belangrikheid van "tradisie" wel beklemtoon, maar dit skyn of dit nie werklik oor "tradisie" gaan nie, maar eerder oor die moontlike voor- of nadele van die gebruik.

Saamwoon buite die huwelik is byna " $n$ onvermydelik tema, aangesien dié verskynsel vandag deur talle mense as plaasvervanger vir en selfs as ' $\mathrm{n}$ verbetering op die huwelik beskou word (Hendrick \& Hendrick, 1992:171; Landale, 1994:949). Die vroue in die studie het die omvang van die saamwoonverskynsel aangeraak en selfs laat blyk dat hulle die saamwoon van ongetroude paartjies bó die huwelik sal verkies: “... I mean if you love your partner and trust him and tell him all the things that you want to share, you can just stay together or something stead of getting married". Verskeie outeurs (o.a. Hutchings \& Delport, 1992:121; Singh, 1996:317) het die toename in die voorkoms van dié verskynsel bevestig. Singh (1996:317) beweer dat die saamwoon van ongetroude paartjies vandag minder gestigmatiseer is, onder andere omdat dié verskynsel toenemend sosiaal aanvaar word. Ook maak die afwesigheid van struktuur en formaliteit dit toenemend populêr. Hutchings en Delport (1992:121) noem weer dat hoe meer paartjies verkies om bloot saam te woon, hoe makliker word dit vir ander om dié proses na te volg.

Die deelnemers het veral twee redes genoem vir hul keuse om eerder saam te woon as in die huwelik te tree. Eerstens voel deelnemers dat die huwelik sy betekenis verloor het: “... I think it's losing meaning, the whole point of marriage. That's why many people say it's better to stay with people, just to cohabit ...". Tweedens meen hulle dat dit onnodig is om bogadi te betaal: “... Marriage is just a waste of time, money and ... it's unnecessary to take out the lobola and those stuff. I think it is unnecessary." Hutchings en Delport (1992:122) noem nog 'n belangrike faktor: die huwelik word dikwels geassosieer met manlike dominansie en daar word aanvaar dat die tradisionele huwelik ongelykheid afdwing. Saamwoon aan die ander kant verteenwoordig `n meer buigsame, vrye en gelyke verhouding.

\section{Verwagting van huweliksmaat}

Die Tswana-vroue wat aan die ondersoek deelgeneem het, het baie spesifieke verwagtinge van hul aanstaande huweliksmaats. Norment (1998:1) bevestig dat hedendaagse vroue hoër verwagtinge van hul metgeselle en verhoudings koester. Drie verwagtinge is uitgesonder, naamlik die huweliksmaat se vermoë om in behoeftes te voorsien, vermoë om te kommunikeer en ' $n$ huwelik op ' $\mathrm{n}$ vennootskapsverhouding gebaseer. 
Dit kom voor of die hedendaagse ongetroude Tswana-vrou meer bewus is van haar eie behoeftes binne die huwelik en sterk ingestel is op haar toekomstige huweliksmaat se vermoë om in hierdie behoeftes te voorsien: “... you have to tell yourself that 'I want this and I don't want this' and you have to sit down with your husband and tell him that I like this and this ... and I don't like this and this and this ...". Steyn (1999:59) noem dat die swart vrou se verwagtings van die huwelik dikwels Westersgeoriënteerd is - so ook haar emosionele en persoonlike behoeftes, en sy maak op haar man staat om hierin te voorsien. Laasgenoemde vereiste dui op vroue se gevoel van eiewaarde en outonomie - heeltemal in kontras met die onderdanige en minderwaardige selfkonsep van sommige vroue.

Die vroue het ook die belangrikheid van kommunikasie binne die huwelik aangeraak, omdat nie van hul huweliksmaats verwag kan word om in hul behoeftes te voorsien indien hulle nie eers weet wat daardie behoeftes is nie: “... 'cause to communicate with some one, to know what I need or what I want, and I know the same about you, that will take us far." Ook relevante vakliteratuur bevestig die belangrikheid van kommunikasie binne die huwelik omdat dit tot 'n toename in deling, empatie en begrip lei, sodat 'n samehorigheidsgevoel ontstaan (Butler \& Joyce, 1998:91; Sperry \& Carlson, 1991:50). Tradisioneel was die vrou nie toegelaat om haar opinie te lug of met die neem van besluite te help nie. Die voorreg van hierdie tipe kommunikasie was uitsluitlik deel van die man se rolbeskrywing: "... long time ago ... the last word of the husband was the last word and he was the one making decisions and so forth, but now there is communication ... they decide together ... In the past the woman didn't have a say in the house ...”.

Vroue is egter nie meer bereid om `n onderdanige posisie ten opsigte van hulle mans in te neem nie; sy soek ' $\mathrm{n}$ huwelik wat ' $\mathrm{n}$ vennootskap is, nie een waarin die man die enigste besluitnemer is en van haar verwag om bevele uit te voer nie: “... they use this thing 50/50 ... if I'm doing the cooking, the man must clean the dishes". Norment (1998:1) stem saam dat die hedendaagse swart vrou 'n maat soek wat haar vennoot kan wees en nie haar besluitnemer nie.

\section{BESPREKING}

Uit `n kontrole vanuit relevante vakliteratuur het geblyk dat ongetroude Tswana-vroue `n ernstige interne konflik beleef tussen hul strewe na eiewaarde en outonomie en hul tradisionele verwagtings. Rabin (1996:14-35) wys vanuit 'n Westerse en 'n kruiskulturele perspektief ook op die interne konflik by die hedendaagse vrou. Volgens Rabin (1996:14) word byvoorbeeld van die vrou verwag om haar moederlike tuisteskepper- en emosionele versorgersrol voort te sit, maar om die fokus op selfverwesenliking en individuele prestasie daarby te inkorporeer. Tswana-vroue wat aan die ondersoek deelgeneem het, is ook bewus van hierdie verwagting. Dit blyk of dit die primêre oorsaak van hul interne konflik ten opsigte van hul hedendaagse strewe en tradisionele verwagtinge kan wees.

Rabin (1996:27) bevestig die onvermoë om hedendaagse verwagtinge met die tradisionele te vereenselwig - ook in die Westerse kultuur. Volgens Rabin (1996:14) speel sosiale instellings ook 'n belangrike rol by die keuse van 'n moderne teenoor tradisionele leefstyl. So kan sosiale instellings soos skole en kerke die tradisionele ondersteun, terwyl die media byvoorbeeld weer eerder verandering aanmoedig. Hierdie teenstrydige boodskappe waaraan die ongetroude volwasse Tswana-vrou daagliks blootgestel word, kan haar interne konflik selfs vererger.

Rabin (1996:16) bespreek egter nog 'n belangrike veranderlike wat volgens haar die primêre oorsaak van talle interne konflikte kan wees, naamlik "geslags- en magskwessies". Wat hierdie veranderlike so "gevaarlik" maak, is dat 'n mens grootliks onbewus van die dinamiek daarvan is. Tydens die empiriese ondersoek vir hierdie artikel is tekens van angstigheid by Tswana-vroue oor 
verandering opgemerk, byvoorbeeld die dominante standpunt dat bogadi behoue moet bly. Wat egter opvallend was, was die deelnemers se gewilligheid en selfs gretigheid om verandering ten opsigte van die "woon-by-skoonouers-gebruik" te aanvaar. Dit skyn dus of die ongetroude Tswana-vrou gewilliger is om verandering te aanvaar indien die verandering vir hulle meer voordele inhou en die risiko van die "sosiale straf" wat met so 'n verandering gepaardgaan, gering is.

Rabin (1996:31) beweer ook dat die vrou in baie gevalle werklik wil verander, maar dat sy voel dat haar opsies beperk is en vrees dat die uitdaging van haar eggenoot se onttrekkende gedrag moontlik tot ' $n$ egskeiding kan lei. Rabin het in haar studie bevind dat vroue se huwelikstevredenheid toeneem as hul mans hulle met huishoudelike takies help. Die man ervaar egter `n verhoogde gevoel van ontevredenheid en `n verlaagde gevoel van aangetrokkenheid tot sy vrou sodra hy besef dat sy meer hulp van hom verwag. Die vrou, wat instinktief aanvoel dat ' $n$ toename in haar versoek om hulp die kwaliteit van haar huweliksverhouding kan benadeel, trek dus hierdie versoek terug en beweeg terug na die status quo. Die belangrikheid van steunstelsels vir die vrou wat self ' $\mathrm{n}$ beroep beklee, is ook beklemtoon, en die man is as een van haar primêre steunstelsels geïdentifiseer. Rabin toon aan dat dit nie so eenvoudig is om van die man te verwag om met huishoudelike takies te help nie. Tswana-vroue wat aan die ondersoek deelgeneem het en skrywers soos Naude (1998:14-15) en Van Zyl (1994:4-5 en 1996:21-23) wat voorstanders is van "die man as steunstelsel", het dus nie die moontlikheid van 'n afname in huweliksgeluk, wat hiermee gepaard kan gaan, in ag geneem nie.

Dit was duidelik dat ' $n$ sekere vrees vir verandering by Tswana-vroue bestaan. Hierdie vrees vir verandering en die interne konflik wat daarmee gepaardgaan, kan egter in 'n groot mate uitgeskakel word deur die aanbieding van 'n toepaslike kultuurkongruente huweliksvoorbereidingsprogram

\section{GEVOLGTREKKINGS EN AANBEVELINGS}

Die ongetroude volwasse Tswana-vrou ervaar vandag verwarring ten opsigte van haar persepsies van die huwelik. Dit skyn of die meerderheid ongetroude volwasse Tswana-vroue graag in die huwelik sal wil tree (alhoewel eers op 'n hoër ouderdom), maar dat hulle terselfdertyd besef waaraan hulle hulleself dan moontlik sal blootstel. 'n Aantal faktore wat moontlik 'n negatiewe invloed op die ongetroude volwasse Tswana-vrou se huwelikspersepsies kan hê, is geïdentifiseer, naamlik egskeiding, ontrouheid, die bogadi-gebruik, die woon by skoonouers en die Tswana-vrou se verwagting van haar huweliksmaat.

Dit kom ook voor of hierdie faktore `n primêre invloed het op sommige ongetroude volwasse Tswana-vroue se keuse om eerder enkellopend te bly of bloot saam met hul maat te woon. Indien hulle wel besluit om in die huwelik te tree, verkies hulle om dit op `n hoër ouderdom te doen en hul huwelik meer Westers te oriënteer. Hul onafhanklikheid is vir hulle baie belangrik en kwalifikasies en ' $n$ beroep word gesien as die medium om hulle sekuriteit te verseker.

Die deurlopende patroon van intense interne konflik ten opsigte van die tradisionele gebruike en die hedendaagse tendense by die ongetroude Tswana-vroue, kan egter in ' $\mathrm{n}$ groot mate uitgeskakel of beperk word deur die aanbieding van in toepaslike kultuurkongruente huweliksvoorbereidingsprogram. Sodanige program behoort op 'n integrale wyse die kwessie van tradisionele versus hedendaagse eise te inkorporeer en in besonder aan die volgende onderwerpe aandag te skenk:

Keuse rakende toekomstige huwelikstatus. 
Persepsies en verwagtinge rakende geslagsrolle en status in die huwelik, maar ook in die algemeen.

Faktore wat huweliksgeluk bedreig.

Die invloed van spesifieke kulturele gebruike, soos bogadi en die woon by die skoonouers, op persepsies oor die huwelik.

\section{BIBLIOGRAFIE}

BUTLER, C. \& JOYCE, V. 1998. Counselling couples in relationships: An introduction to the relate approach. Chichester: Wiley.

DOBSON, C.D. \& HOUSEKNECHT, S.K. 1998. Black and white differences in the effect of women's educational attainment on age at first marriage. Journal of Family Issues, 19(2):204 (20p). In: EBOSCOHOST: Academic Search Elite, Full display:

http://www-sa.ebsco.com [Date of access: 21 Junie 2002]

DU PREEZ, M.S.E. \& VAN NIEKERK, C.E. 1988. Huweliksvoorligting met geselekteerde groepe swart studente deur middel van groepwerk. Social Work/ Maatskaplike Werk, 24(3):154163.

HENDRICK, S. \& HENDRICK, C. 1992. Liking loving and relating ( $2^{\text {nd }}$ ed). California: Brooks/Cole.

HUTCHINGS, S. \& DELPORT, E. 1992. Cohabitation: A responsible approach. De Rebus, 120125.

KIMATHI, G. 1994. Your marriage and family. Potchefstroom: PU for CHE.

LABUSCHAGNE, J.M.T. 1991. Regsakkulturasie, lobolo-funksies en die oorsprong van die huwelik. Tydskrif vir Hedendaagse Romeins-Hollandse Reg, 54:541-553.

LANDALE, N.S. 1994. Nonmarital cohabitation and childbearing among black and white American women. Journal of Marriage and the Family, 56:949-962.

LASSWELL, M. \& LASSWELL, T. 1991. Marriage and the family ( ${ }^{\text {rd }}$ ed). California: Wadsworth.

LAVILLE, R. 1999. In the shadow of marriage: Gender and justice in an African community. Journal of Contemporary African Studies, 17(1):150-152.

LEVITZ, E. 1995. Women in South Africa : From transition to governance. Publico, 15(4):25-27.

MAKHOLWA, A. 1997. Is lobola outdated? Pace:110-111.

MASHISHI, A. 2000. Wife battering: An exploration of the abuse of African women at two shelters in Johannesburg. Society in Transition, 31(1):82-87.

MVIMBI, T.D. 2000. The high price of lobola. Pace:120-121.

NAUDE, C. 1998. Strem gesinne loopbane? Finansies \& Tegniek, 50(15):14-15.

NORMENT, L. 1998. Sex and the new black woman: Myths and realities. Ebony, 53(5):104. In: EBOSCOHost: Academic Search Elite, Full display. Available: http://www-sa.ebsco.com [Date of access : 21 Junie 2002]. 
POGGENPOEL, M. 1998. Data analysis in qualitative research. In: DE VOS, A.S. (ed) Research at grass roots: A primer for the caring professions. Pretoria: Van Schaik.

RABIN, C. 1996. Equal partners good friends: Empowering couples through therapy. London: Routledge.

SCHAPERA, I. 1971. Southern Africa part iii: The Tswana. London: Lowe \& Brydone.

SCHAPERA, I. 1994. A handbook of Tswana law and custom: Compiled for the Bechuanaland Protectorate Administration. London: LIT.

SIKHITHA, T.M. 1996. Social work practice in cross-cultural situations: some guidelines for practice. Maatskaplike Werk/Social Work, 32(1):61-66.

SINGH, D. 1996. Cohabitation relationships revisited: Is it not time for acceptance. The comparitive and international law journal of Southern Africa, 29:317-318.

SOUTH, S.J. 1993. Racial and ethnic differences in the desire to marry. Journal of marriage and the family, 55:357-370.

SPERRY, L. \& CARLSON, J. 1991. Marital therapy: Integrating theory and technique. Denver: Love.

STEYN, M.G. 1999. Die noodsaaklikheid en aard van `n huweliksvoorbereidingsprogram vir swart laat-adolessente. Social Work Practitioner-Researcher, 11(2):52-64.

STRYDOM, H. 2000. Maatskaplikewerknavorsing (MWK 321/411). Potchefstroom: PU vir CHO.

VAN DER VLIET, V. 1991. Traditional husbands, modern wives?: Constructing marriages in South African townships. African Studies, 50(1):219-241.

VAN ZYL, L. 1994. Vroue kom tot hul reg. Publico, 14(5):4-5.

VAN ZYL, L. 1996. Huisvrou vs beroepsvrou. Publico, 16(2):21-23.

WOODS, N.F. \& CATANZARO, M. 1988. Nursing research: Theory and practice. St Louis: Mosby.

Me A Erasmus was 'n maatskaplike werker by die Kindersorgvereniging in Potchefstroom, Suid-Afrika.

Me EH Ryke is `n senior dosent aan die Potchefstroom Kampus van die NoordwesUniversiteit, Potchefstroom, Suid-Afrika. 